УДК: 659.126:339.1

https://doi.org/10.52058/2708-7530-2021-3(9)-229-240

Якобчук Валентина Павлівна кандидат економічних наук, професор, завідувач кафедри економічної теорії, інтелектуальної власності та публічного управління, Поліський національний університет, бульвар Старий, 7, м. Житомир, 10008, e-mail: valentyna.iakobchuk@ gmail.com, https://orcid.org/0000-0003-2147-7994

Захаріна Оксана Володимирівна кандидат економічних наук, доцент кафедри економічної теорії, інтелектуальної власності та публічного управління, Поліський національний університет, бульвар Старий, 7, м. Житомир, 10008, e-mail: ovzakharina@ukr.net, https://orcid.org/0000-0002-2622-7663

Кравець Ірина Вікторівна кандидат економічних наук, доцент кафедри економічної теорії, інтелектуальної власності та публічного управління, Поліський національний університет, бульвар Старий, 7, м. Житомир, 10008, e-mail: ikravets2009@ukr.net, https://orcid.org/0000-0001-5919-6560

\title{
СУЧАСНІ ІННОВАЦІЙНО-ТЕХНІЧНІ РІШЕННЯ У СФЕРІ УПРАВЛІННЯ БРЕНДОМ: ТЕХНОЛОГІЯ БРЕНДИНГУ
}

Анотація. Досліджено теоретичні і прикладні засади брендингу. Розглянуто сутність поняття «бренд» та обгрунтовано доцільність застосування технології брендингу в політиці компанії. Аргументовано переваги брендингу, що включає цілий комплекс заходів 3 розвитку іміджу та закріплення довгострокових відносин компанії зі споживачем, завдяки чому створюється унікальний стиль, підвищується цінність продукту і формується довіра до носія бренду.

Під технологією брендингу запропоновано розуміти комплекс методів, прийомів та засобів щодо створення й розвитку брендів. Здійснено концептуалізацію технології брендингу 3 урахуванням таких інструментів, як неймінг, розробка фірмового стилю, бренд-бук та ребрендинг. Доведено дієвість використання методів формування імені бренду 3 урахуванням специфіки компанії. Визначені елементи фірмового стилю, який посилює ефективність рекламних контактів зі споживачем, підвищує публічну популярність і довіру партнерів, допомагає зміцнювати репутацію бренду, стає необхідною умовою досягнення стійкого і тривалого ділового успіху. 
Обгрунтовані групи логотипів і визначені переваги кожної 3 них. Наголошено, що при розробці логотипу приділяється увага i формування кольорової гами, оскільки науково доведено, що колір емоційно впливає на людину. Наведені приклади асоціативної ролі кольору. Розкрита сутність брендбуку, яка полягає в описі атрибутів бренду, за допомогою яких споживач сприймає, запам'ятовує, дізнається про бренд і формує його позитивний образ. Це регламент компанії про їі фірмовий (корпоративний) стиль: елементи фірмового стилю, комунікації і цінності компанії. Наголошено, що ідеальний бренд-бук повинен складатися 3 трьох блоків: платформи бренду, паспорту стандартів та інструкції.

Аргументована доцільність технології ребрендингу. Передумовами для iї впровадження визначені зміни умов ринку; поява більш сильних конкурентів; неактуальність бренду на ринку; зміна його ролі в портфелі брендів компанії, наприклад, з’явився більш успішний бренд, орієнтований на ту ж цільову аудиторію; перед брендом можуть бути поставлені більш амбітні завдання за обсягом продажу, а цільова аудиторія, на яку він був орієнтований з початку, не достатня за своєю чисельністю або купівельною спроможністю, тому постає необхідність переорієнтації на іншу аудиторію тощо. Підкреслена роль ребрендингу 3 метою виведення компанії на абсолютно новий етап розвитку, привернення уваги не охопленої раніше аудиторії i, відповідно, розширення впливу бренду на ринку.

Ключові слова: бренд, брендинг, технологія брендингу, неймінг, логотип, фірмовий стиль, бренд-бук, ребрендинг.

Yakobchuk Valentyna Pavlivna PhD of Economic Sciences, Professor, Head of the Department of Economic Theory, Intellectual Property and Public Administration, Polissia National University, Stary Blvd, 7, Zhytomyr, 10008, e-mail: valentyna.iakobchuk@gmail.com, https://orcid.org/0000-0003-2147-7994

Zakharina Oksana Volodymyrivna $\mathrm{PhD}$ of Economic Sciences, Associate Professor of Department of Economic Theory, Intellectual Property and Public Administration, Polissia National University, Staryi Blvd., 7, Zhytomyr, 10008, e-mail: ovzakharina@ukr.net, https://orcid.org/0000-0002-2622-7663

Kravets Iryna Viktorivna PhD of Economic Sciences, Associate Professor of Department of Economic Theory, Intellectual Property and Public Administration, Polissia National University, Stary Blvd., 7, Zhytomyr, 10008, e-mail: ikravets2009@ukr.net, https://orcid.org/0000-0001-5919-6560 


\title{
MODERN INNOVATIVE AND TECHNICAL SOLUTIONS IN THE FIELD OF BRAND MANAGEMENT: BRANDING TECHNOLOGY
}

\begin{abstract}
In the article we investigate the theoretical and applied principles of branding. The essence of the concept of "brand" is considered and the expediency of application of branding technology in the company policy is substantiated. The advantages of branding are argued, which includes a range of measures to develop the image and consolidate long-term relationships of the company with the consumer, which creates a unique style, increases the value of the product and builds trust in the brand. Under branding technology, it is proposed to understand a set of methods, techniques and tools for creating and developing brands.
\end{abstract}

The conceptualization of branding technology was carried out taking into account such tools as naming, corporate identity development, brand book and rebranding. The effectiveness of using methods of brand name formation taking into account the specifics of the company is proved. Certain elements of corporate style, which enhances the effectiveness of advertising contacts with consumers, increases public popularity and trust of partners, helps to strengthen the brand reputation, becomes a necessary condition for achieving sustainable and long-term business success.

The groups of logos are substantiated and the advantages of each of them are determined. It is emphasized that when designing a logo, attention is paid to the formation of colors, as it has been scientifically proven that color affects a person emotionally. Examples of the associative role of color are given. The essence of the brand book is revealed, which consists in the description of the attributes of the brand, by means of which the consumer perceives, remembers, learns about the brand and forms its positive image. This is the company's regulations on its corporate (corporate) style: elements of corporate style, communication and company values. It is emphasized that the ideal brand book should consist of three blocks: the brand platform, the passport of standards and instructions.

The expediency of rebranding technology is argued. Prerequisites for its implementation are changes in market conditions; the emergence of stronger competitors; irrelevance of the brand in the market; changing its role in the company's brand portfolio, for example, a more successful brand aimed at the same target audience; The brand may be faced with more ambitious sales targets, and the target audience it has targeted from the beginning is not sufficient in number or purchasing power, so there is a need to reorient to another audience, and so on. The role of rebranding is emphasized in order to bring the company to a completely new stage of development, to attract the attention of the audience not previously covered and, accordingly, to expand the brand's influence in the market.

Keywords: brand, branding, branding technology, naming, logo, corporate 
identity, brand-book, rebranding.

Постановка проблеми. Сьогодні знання інноваційних рішень у сфері управління брендом неабияк цінні, оскільки кількість торговельних марок щорічно збільшується, а ознаки їх відмінності скорочуються, і споживачу в умовах вибору все важче цей вибір зробити. I ця проблема характерна не тільки для країн з розвиненою ринковою економікою, вона актуальна і для України. Збільшення товарних категорій i, як наслідок, зростання конкурентів призводить до висування на перший план якості товарів і послуг, різноманітності різних способів контакту з споживачем. Однак більшість конкурентів роблять ті ж самі кроки. В результаті власники торгових марок відкривають нові технології нецінової конкуренції, однією з яких стає створення і розвиток сильного бренду.

Аналіз останніх досліджень і публікацій. У науковій літературі брендинг розглядається як обов'язковий елемент економічної політики компанії. При цьому дослідження спираються на багату зарубіжну практику в сфері управління брендами. Так, у західній науковій літературі питання брендингу широко висвітлені в працях Ф. Котлера [6], І. Рейна, М. Хемліна, М. Стіллера, У. Оллінса, Д. Траута, Н. Фіцджеральда, М. Портера, Д. Аакера [1], С. Анхольта [2, 4], Е. Чемберліна, Дж. Робінсона. Фундамент вивчення проблем управління брендом та технологій брендингу заклади науковці Н. Кляйн, Е. Шлоссер, Р. Франк, Ф. Бегбедер, А. Дюамель, Ж. Бодрійяр, І. Барель, Ж. Липовецький, М. Маффесолі, Г. Мині, Д. Шнайдер. Серед вітчизняних дослідників, що вивчають питаннями брендингу відмітимо К. Зенкена, Д. Візгалова, О. Власенко, О. Кендюхова, Ю. Приходько, А. Давидова, А. Гальчинського, О. Соскіна, В. Мірошниченко.

Водночас, недостатня дослідженість сучасних інноваційно-технічних рішень у сфері управління брендом свідчить про актуальність і необхідність більш глибоких досліджень.

Мета статті - обгрунтувати сутність та специфіку технології брендингу як сучасного інноваційно-технічного рішення у сфері управління брендом.

Виклад основного матеріалу. В умовах зростаючої конкуренції все більше значення приділяється брендингу та його технологіям. Брендинг - це створення позитивного образу компанії (корпоративний та товарний брендинг), території (територіальний, географічний і національний брендинг), політичної партії та іiі кандидата (політичний брендинг), особистості (персональний брендинг), його поширення та закріплення в свідомості споживачів. Іншими словами - це управління брендом, що включає цілий комплекс заходів з розвитку іміджу та закріплення довгострокових відносин зі споживачем. Завдяки йому створюється унікальний стиль, підвищується цінність продукту і формується довіра до носія бренду. 
Визначення «branding» походить від латинського слова «brand»- клеймо. В Свропі з давніх часів почали таврувати вироби фірмовими знаками, щоб люди дізнавалися, хто виготовив товар. Зі зростанням обсягів виробництва, асортимент продукції, представлений на ринку, істотно зріс. У зв’язку з цим компанії намагалися виділитися з числа конкурентів за допомогою брендування [6]. За фактом, продавець пропонував потенційному споживачу не просто товар, а цілу екосистему споживання - його ідею, цінності, образ і життя, емоції.

При цьому брендинг не може грунтуватися на одній інтуїції. Формування сильного бренду передбачає глибоке розуміння ринкової ситуації і особливостей його сприйняття різною цільовою аудиторією [7]. Пов’язані з цим завдання неможливо вирішити одноразово, тому брендинг є системою поетапних заходів 3 відповідною технологією створення та управління брендом. Під технологією брендингу будемо розуміти комплекс методів, прийомів та засобів щзодо створення й розвитку брендів.

Важливо відмітити, що кожен бренд має чисту вартість, і ця вартість зростає в міру зростання прихильності до нього. Чим більшу додану вартість (brand equity) здатний створювати бренд, тим краще. I тому, розглядаючи управління брендом, будемо говорити, перш за все, про управління вартістю бренду шляхом використання сучасних технологій брендингу. Серед останніх виділяємо неймінг, розробку фірмового стилю, бренд-бук та ребрендинг.

Термін неймінг (від англ. to name - називати, давати ім'я) вперше з'явився в кінці XIX ст. і являє собою професійну діяльність з розробки назви бренду [8]. Це один з найпотужніших і пам'ятних ідентифікаторів продукту або компанії. Назви можуть бути емоційними, традиційними, суперечливими, дивними, провокаційними, поетичними, звучними, багатозначними. Головне, щоб вони легко запам’ятовувалися і працювали. Варто відмітити, що завданнями неймінгу є просування на ринок товарів та послуг, захист їх від підробок та інших видів нелегального використання, сприяння зростанню доходів власнику бренда.

Розглянемо основні методи формування імені бренду.

Один 3 найпростіших способів назвати компанію - це надати їй прізвище засновника компанії. Так, наприклад, фірма Johnson \& Johnson, виробник медичного обладнання та приладів для діагностики, лікарських препаратів i товарів для гігієни і здоров’я людини, названа в честь засновників компанії братів Джонсон. Британська компанія 3 виробництва кондитерських виробів Cadbury отримала назву завдячуючи імені родини Кедбері, яка іiі і заснувала. За даним принципом утворені такі бренди, як: компанія з виробництва побутової техніки Philips, концерн в галузі електротехніки та електроніки Siemens, мережа готелів Hilton, виробник телекомунікаційного устаткування Ericsson, один 3 лідерів світового ринку споживчих товарів Procter and Gamble. 
Наступний поширений метод в світовій практиці - назва компанії за допомогою топоніма (географічної назви). В даному випадку увага приділяється місцю знаходження компанії. За таким принципом утворені такі світові бренди, як: сигарети Winston, лікер Malibu, телекомунікаційна компанія Nokia, інтернетмагазин Nottingham, найбільший виробник шоколадних батончиків в Північній Америці Hershey. Топоніми присутні в назві авіакомпаній Air Asia i Air Serbia, в назві Британської компанії, найбільшого в світі оператора аеропортів Heathrow Airport Holdings.

Ім'я бренду може грунтуватися i на алітерації - ритмічних повторах однакових i однорідних приголосних звуків. Наприклад, напій Coca-Cola, льодяники на паличці Chupa-Chups, шоколадні батончики KitKat, популярні солодкі драже Tic-Tac.

Нерідко тварина, рослина чи природне явище асоціюються зі властивостями продукту: британська автомобільна компанія Jaguar, компанія Camel - одна 3 найстаріших і найпрестижніших тютюнових марок світу, компанія з виробництва автомобільної сигналізації Alligator, Thames Water - британська компанія, надає послуги з водопостачання, Kangaroo - найбільший в Південній Кореї виробник автохімії та автокосметики. Американська інтернет-компанія Amazon була названа на честь річки Амазонки, найбільш повноводною в світі. Глобальний сервіс мікроблогів Twitter отримав своє ім'я від англійського дієслова to twitter «чірікать, щебетати».

Досить часто для назви компаній використовується абревіатура. 3 відомих абревіатур можна привести такі назви як IBM (International Business Machines) американська компанія, один 3 найбільших в світі виробників і постачальників апаратного і програмного забезпечення, $M S$ (Microsoft) - компанія з виробництва програмного забезпечення для обчислювальної техніки. Компанія з виробництва та продажу засобів особистої гігієни, побутової хімії та косметичних засобів Amway отримала назву при скороченні повного імені American Way of Life «американський спосіб життя» [9].

Назвою бренду може стати складене слово, утворене при складанні двох слів. Наприклад: Mothercare - торгова компанія, яка спеціалізується на реалізації товарів для майбутніх мам і дітей до 10 років, Westvision - англійська компанія, один 3 провідних світових виробників відеотехніки, Safeway -мережа американських продуктових супермаркетів.

Іноді назвою компаній стають словосполучення: Big Society Capital незалежна британська група компаній під єдиним управлінням, що здійснює соціальні інвестиції, British American Tobacco - тютюнова компанія, Golden Boy Promotions - американська компанія, що займається організацією професійних боксерських поєдинків, the Walt Disney Company - один з найбільших фінансових 
конгломератів індустрії розваг у світі.

Найпоширеніший метод - це створення нових слів (неологізмів), які нічого не означають, але можуть стати справжніми брендами. Неологізми мають свої переваги. По-перше, вони не мають перекладу в багатьох мовах і можуть стати міжнародними. По-друге, не викликають ніяких негативних емоцій. По-третє, 3 ними практично ніколи не виникає проблем з реєстрацією товарної марки. Однак неологізми, як правило, складніше виводити на ринок, оскільки потрібно більше зусиль, щоб споживач запам'ятав ім'я і зіставив його з ідеєю бренду. Серед брендів-неологізмів можна виділити такі назви, як: PepsiCo - американська компанія, що виробляє безалкогольний газований напій, Kleenex - одна 3 найвідоміших американських фірм по виробництву і продажу товарів особистої гігієни, Kodak - американська компанія, виробник фототехніки і фототоварів.

Таким чином, методи неймінгу різноманітні. Семантика бренду формується в свідомості людини, забезпечуючи емоційний зв’язок між сприйняттям бренду та його смисловою функціональністю.

Наступним етапом брендингу є розробка фірмового стилю (corporate identity), який посилює ефективність рекламних контактів зі споживачем, підвищує публічну популярність i довіру партнерів, допомагає зміцнювати репутацію бренду, стає необхідною умовою досягнення стійкого i тривалого ділового успіху. Елементами фірмового стилю є логотип і фірмова документація, така як: візитні картки, фірмові бланки, папки, брошури, бейджі та інші елементи. Так, одним із основних складових елементів фірмового стилю є логотип. Даний термін 3'явився на початку XIX ст. в топографії і був синонімом поняття «лігатура», тобто позначав об’єднання двох або трьох знаків типографського шрифту: індивідуальний графічний знак, шрифтове написання марки або поєднання графічного знаку та шрифтового написання [1].

У сучасному розумінні логотип - це оригінальне зображення повного або скороченого найменування компанії або продукту. Логотип оформляється i реєструється відповідно до чинного законодавства та забезпечується правовим захистом з боку держави. Однак, логотип - це не тільки унікальне зображення компанії, але й образ, емоція, пам'ять, елемент, що впливає на підсвідомий вибір споживачів.

Варто відмітити, що логотипу притаманний ряд функцій. По-перше - це асоціативна функція, тобто за допомогою логотипу продукт виділяється серед інших. По-друге - захисна функція. Зареєстрована торгова марка захищає компанію від недобросовісної конкуренції і дозволяє відстояти їі права в суді. Потретє - гарантійна функція. У сприйнятті споживача наявність логотипу компанії зі стійкою діловою репутацією є гарантією якості іiі продукту. Не менш важливими $є$ рекламна функція, інформаційна та психологічна функції, за 
допомогою яких логотип інформує споживачів про виробника, викликає позитивне ставлення споживачів до компанії та її продукту.

Відповідно, до основних завдань логотипу, як базового елементу фірмового стилю, віднесемо:

- сформувати індивідуальність і пізнаваність логотипу;

- полегшити запам'ятовування товару. Прості знаки запам'ятовуються легше. Водночас, оригінальне і складне зображення знайомого предмету запам'ятовується краще, ніж просте зображення незнайомого;

- вказати походження товару. Такий символ завжди йде корінням в культурне середовище. За часту вибирають знаки, що асоціюються 3 культурним укладом країни-виробника;

- проінформувати про товар. Потрібно створити зображення або знайти слово, яке створить бажане уявлення про продукт;

- стимулювати бажання купити;

- символізувати гарантію якості.

За типом виконання логотипи діляться на наступні групи (рис. 1).

До шрифтових логотипів належать логотипи, в яких застосовується тільки текст. Такі логотипи добре запам'ятовуються, легко помітні, більш зручні для реклами, представляючи собою оригінальні слова i назви. Словесні логотипи дуже добре працюють, коли компанія має коротку й чітку назву.

Логотип-символ (графічні логотипи) містить глибоку ідею, i 3 його допомогою можна викликати потрібні емоції у споживачів. Однак дане рішення підходить далеко не всім. 3 таким логотипом складно просунути новий, але неунікальний бізнес. Найбільш успішними графічними логотипами є Apple, Twitter $i$ Android.

За допомогою абстрактного логотипу можна передати ідею бренду, не спираючись на культурно-історичний досвід. Так, за допомогою кольору і форми передаються цінності та емоції бренду. Абстрактні логотипи - найкращий варіант для міжнародних торгових компаній.

Абревіатурні логотипи і монограми - оптимальний варіант для компаній 3 багатослівними назвами. При розробці таких логотипів увагу слід приділяти підбору шрифтів. Накреслення літер не тільки має відповідати стилю i духу компанії, воно також має бути розбірливим, щоб легко можна було прочитати на екранах мобільних телефонів і візитних картках. Ті, хто тільки відкрив бізнес, можуть в перший час розміщувати розшифровку абревіатури під логотипом.

Однією з головних переваг логотипу-талісмана є його здатність комунікувати зі споживачами. Це ефективний інструмент маркетингової діяльності в соціальних мережах (SMM) і проведення промо-акцій в реальному світі. Водночас, такий тип логотипу не скрізь доречний. Наприклад, талісмани досить безглуздо виглядають 
на візитівках.

Шрифтові логотипи

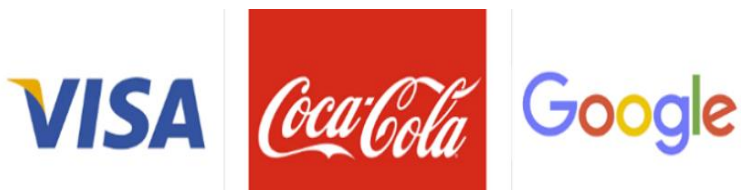

Графічні логотипи
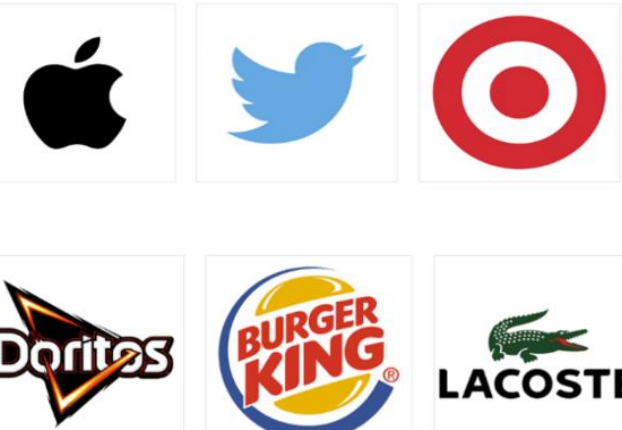

Комбіновані

логотипи
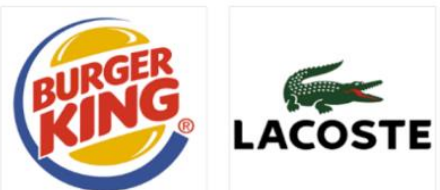

Абстрактні логотипи
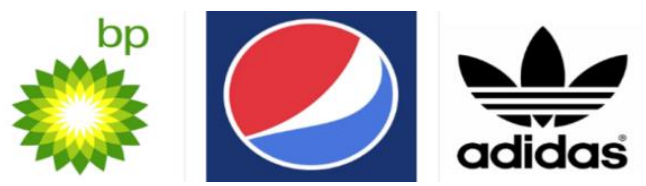

Абревіатури i

монограми
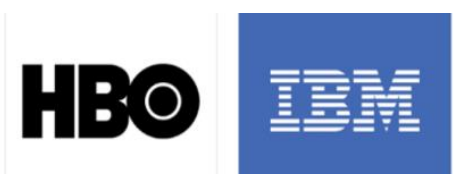

N/SA

Логотип-талісман

Логотип-емблема
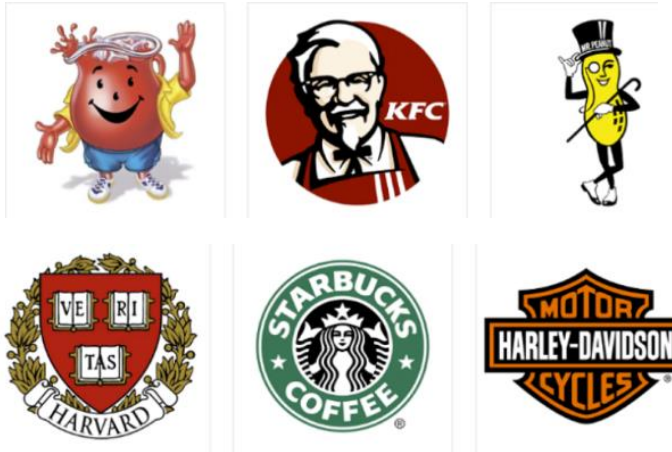

GARIEY-DAVIDSOD

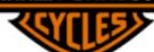

Puc. 1. Групи логотипів

Емблема-логотип містить шрифт всередині символу. Створюються такі логотипи за принципом печаток, гербів, жетонів. Що стосується галузі використання емблем, то краще за все такі фірмові знаки підходять для шкіл, некомерційних організацій, урядових установ, підприємств харчової промисловості. Логотипи даного типу також користуються популярністю у автовиробників. Так, багато таких емблем виглядають старомодно, проте є приклади і вдалої модернізації дизайну. Наприклад, в XXI ст. вдало виглядають оновлені емблеми Harley-Davidson i Starbucks.

Безумовно, при розробці логотипу приділяється увага i формування кольорової гами, оскільки науково доведено, що колір емоційно впливає на 
людину.

Декілька прикладів асоціативної ролі кольору:

- синій - це, безумовно, улюблений колір для технічного брендування Facebook, Intel, Hewlett-Packard, IBM, Epson, Dell, Asus;

- синьо-чорні кольори характерні для металу i більш притаманні машинобудівній галузі, а також всім виробництвам, пов'язаних 3 металом. Наприклад, BMW, Industrial company, Volkswagen, Hyundai;

- червоний колір - завжди звертає на себе увагу і змушує зупинити на ньому свій погляд. Це колір Coca-Cola, Lenovo, Levi’s, Lego, H\&M;

- білий i чорний кольори $\epsilon$ нейтральними i не конфліктують 3 іншими кольорами логотипу, лише доповнюють їх. Нейтральними є і всі градації сірого кольору.

Крім того, логотипи бувають міжнародні, національні, регіональні і локальні. Загальновідомі, або міжнародні логотипи - це знаки, репутація і популярність яких на світовому ринку досягла таких розмірів, що їм надається максимально широка правова охорона. Охорона таких логотипів передбачена Паризькою конвенцією про захист промислової власності і застосовується не тільки до ідентичних і подібних товарів, але і до всіх товарів, незалежно від їх характеру та призначення. Власниками міжнародних знаків є найбільші монополії, які таким чином захищають свої позиції на ринку, виграючи у конкурентній боротьбі.

Важливим етапом брендингу є і створення бренд-буку (brand-book) компаніï. Бренд-бук містить опис атрибутів бренду, за допомогою яких споживач сприймає, запам'ятовує, дізнається про бренд i формує його позитивний образ. Це регламент/положення компанії про її фірмовий (корпоративний) стиль: елементи фірмового стилю, комунікації і цінності компанії. Відмітимо, що ідеальний брендбук повинен складатися з трьох блоків: платформи бренду, паспорту стандартів та інструкції.

Як правило, в першому блоці бренд-бука описується Платформа бренду, що включає місію і філософію бренду, його цінності, ключові ідентифікатори, опис повідомлення бренду, каналів і методів передачі цього повідомлення. Другий блок бренд-бука включає опис логотипу компанії, його побудову, кольорову гаму, допустимі і неприпустимі конвертації й використання, а також містить правила оформлення реклами, сувенірної продукції, уніформи, інтер'єрів і корпоративного транспорту. Існує безліч можливих носіїв фірмового стилю, тому їх кількість $\mathrm{i}$ види при створенні бренд-бука визначається індивідуально. Окремим блоком бренд-бука (іноді він поєднується з паспортом стандартів) може бути оформлена інструкція, яка описує складні, з точки зору технології, процеси зі створення фірмових ідентифікаторів і адаптації їх з носіями фірмового стилю.

Згодом навіть відомі бренди втрачають свою популярність, а отже, i свої 
позиції на ринку. Причинами цього можуть бути зміни умов ринку; поява більш сильних конкурентів; неактуальність бренду на ринку; зміна його ролі в портфелі брендів компанії, наприклад, з'явився більш успішний бренд, орієнтований на ту ж цільову аудиторію; перед брендом можуть бути поставлені більш амбітні завдання за обсягом продажу, а цільова аудиторія, на яку він був орієнтований 3 початку, не достатня за своєю чисельністю або купівельною спроможністю, тому постає необхідність переорієнтації на іншу аудиторію тощо. Іноді компанія розширює лінійку продуктів, плануючи вийти на новий рівень. У всіх цих випадках просто необхідний ребрендинг. Він здатний не тільки пожвавити старий бренд, але і вивести його на абсолютно новий етап розвитку, привернути увагу не охопленої раніше аудиторії і, відповідно, розширити вплив бренду на ринку.

Висновки. Підводячи підсумок відмітимо, що процес створення бренду i подальшого управління ним - цілком логічний, передбачуваний і керований. При цьому потрібно враховувати, що бренд 3 усіма його атрибутами, ідентифікаторами та вартісними характеристиками існує, перш за все, в свідомості споживачів. Логотип і слоган, нехай навіть створені за технологіями «впливу на вибір споживача», не можуть гарантувати успіх. Споживачу потрібен той товар, який він готовий і хоче купити. I нарешті, йому потрібні свої особисті вигоди і уподобання. Адже саме вони визначають стабільну прихильність до будь-якого об'єкта споживання. Це і лежать в основі такого поняття, як бренд, а управління брендом 3 використанням сучасних технологій брендингу стає необхідною умовою виживання і зростання компанії в умовах зростаючої конкуренції.

\section{Jimepamypa:}

1. Аакер Д., Йохимштайлер Э. Бренд-лидерство: новая концепция брендинга. Москва : Издательский дом Гребенникова, 2003. 380 с.

2. Анхольт С. Создание бренда страны. Бренд-менеджер. 2007. № 1. С. 36-44.

3. Асоціація випускників Програми стажування у Верховній Раді України та інших органах влади. «Наше завдання зробити так, щоб сумних історій не було», - Василь Мірошниченко про імідж України. URL : http://www.interns.org.ua/uk/content/nashe-zavdannyazrobyty-tak-shchob-sumnyh-istoriy-ne-bulo-vasyl-miroshnychenko-pro-imidzh

4. Брендинг: дорога к мировому рынку / Симон Анхолт ; [пер. с англ. Ю. В. Алабина]. Москва : КУДИЦ-ОБРАЗ, 2004. 270 с.

5. Забезпечення інформаційної безпеки держави. URL https://pidru4niki.com/82886/politologiya/zabezpechennya_informatsiynoyi_bezpeki_derzhavi

6. Маркетинг от А до Я: 80 концепций, которые должен знать каждый менеджер / Филип Котлер ; пер. с англ. Москва : Альпина Паблишерз, 2010. 211 с.

7. Eshuis J., Edwards A. Branding the city: The democratic legitimacy of a new mode of governance. Urban Studies. 2013. Vol 50 (5). P. 1066-1082.

8. Eshuis J., Klijn E.-H. Branding in governance and public management. New York: 
Routledge. 2012. 188 p.

9. Hankinson Graham. Relational Network Brands: Towards a Conceptual Model of Place Brands. Journal of Vacation Marketing. 2004. 10 (2). P. 109-121.

10. Karens R. J., Eshuis E. H., Klijn J. V. The impact of public branding: an experimental study on the effect of branding policy on citizen trust. Public Administration Review. 2016. Vol 76 (3). P. 486-494.

11. Marsh D., Fawcett P. Branding, politics and democracy. Policy Studies. 2011. 32 (5). P. $515-530$.

\section{References:}

1. Aaker, D. \& Jokhymshtajler, E. (2003). Brend-liderstvo: novaja koncepcija brendinga [Brand Leadership: A New Branding Concept]. Russia: Izdatel'skij dom Grebennikova [in Russia].

2. Anhol't, S. (2007). Sozdanie brenda strany [Country brand creation]. Brend-menedzher, vol. 1., pp. 36-44 [in Russia].

3. Sait Asotsiatsii vypusknykiv Prohramy stazhuvannia u Verkhovnij Radi Ukrainy ta inshykh orhanakh vlady. [Site of the Association of Vipuskniks Programs of internship with the Verkhovna Rada of Ukraine and other authorities]. http://www.interns.org.ua. Retrieved from http://www.interns.org.ua/uk/content/nashe-zavdannya-zrobyty-tak-shchob-sumnyh-istoriy-ne-bulovasyl-miroshnychenko-pro-imidzh [in Ukrainian].

4. Simon, Anholt (2004). Brending: doroga k mirovomu rynku [Branding: the road to the global market]. Russia: KUDIC-OBRAZ [in Russia].

5. Sait Zabezpechennia informatsijnoi bezpeky derzhavy [Security information security of the state]. https://pidru4niki.com.ua. Retrieved from https://pidru4niki.com/82886/politologiya/ zabezpechennya_informatsiynoyi_bezpeki_derzhavi [in Ukrainian].

6. Kotler, Filip (2010). Marketing ot A do Ja: 80 koncepcij, kotorye dolzhen znat' kazhdyj menedzher [Marketing from A to Z: 80 Concepts Every Manager Should Know]. Russia: Al'pina Pablisherz [in Russia].

7. Eshuis, J. \& Edwards, A. (2013). Branding the city: The democratic legitimacy of a new mode of governance. Urban Studies, vol 50 (5), pp. 1066-1082 [in English].

8. Eshuis, J. \& Klijn, E.-H. (2012). Branding in governance and public management. New York: Routledge [in English].

9. Hankinson, Graham (2004). Relational Network Brands: Towards a Conceptual Model of Place Brands. Journal of Vacation Marketing, vol. 10 (2), pp. 109-121 [in English].

10. Karens, R. J., Eshuis, E. H. \& Klijn, J. V. (2016). The impact of public branding: an experimental study on the effect of branding policy on citizen trust. Public Administration Review, vol 76 (3), pp. 486-494 [in English].

11. Marsh, D. \& Fawcett, P. (2011). Branding, politics and democracy. Policy Studies, vol. 32 (5), pp. 515-530 [in English]. 